\title{
Clinical, behavioral and biochemical alterations due to shearing stress in Ossimi sheep
}

\author{
Abdelghany HEFNAWY'), Mahmoud Atef Youssef HELAL ${ }^{1)}$, Ahmed SABEK ${ }^{2) *}$ \\ and Saad SHOUSHA ${ }^{3)}$ \\ 1)Department of Animal Medicine, Faculty of Veterinary Medicine, Benha University, Moshtohor, \\ Kalyobiya 13736, Egypt \\ ${ }^{2)}$ Department of Veterinary Hygiene and Management, Faculty of Veterinary Medicine, Benha University, \\ Moshtohor, Kalyobiya 13736, Egypt \\ ${ }^{3)}$ Department of Animal Physiology, Faculty of Veterinary Medicine, Benha University, Moshtohor, \\ Kalyobiya 13736, Egypt
}

\section{J. Vet. Med. Sci. \\ 80(8): 1281-1286, 2018}

doi: 10.1292/jvms.18-0150

Received: 18 March 2018

Accepted: 7 June 2018

Published online in J-STAGE:

25 June 2018
ABSTRACT. The effects of shearing on behavioral patterns, antioxidants, and inflammatory and stress biomarkers was investigated in Ossimi sheep. Clinical parameters and behavioral patterns were recorded, and serum samples were collected pre-shearing and 1, 5, 10 and 15 days postshearing from 60 Ossimi sheep. The results revealed that grooming and standing idle frequencies were significantly $(P<0.01)$ increased post-shearing. There were significant $(P<0.01)$ increases in IL-6, cortisol, and MDA detected from the 1st to the 10th day post-shearing compared to pre-shearing values. IL-2 and TNF-a significantly $(P<0.01)$ increased from the 1 st until the 5 th day post-shearing compared to pre-shearing values, while significant $(P<0.01)$ decreases in the values of catalase from the 1 st until the 5 th day post-shearing compared to pre-shearing values were recorded. Regarding to glutathione reductase, there was a significant $(P<0.01)$ decrease from the 1 st until the 10th day post-shearing compared to pre-shearing values. Shearing leads to significant changes in antioxidants, inflammatory, stress biomarkers, and some behaviors in sheep.

KEY WORDS: behavior, oxidative stress, physiology, shearing

Routine management procedures in sheep breeding, such as shearing, isolation and transportation induce some biological changes known as stress [7, 29]. The reaction to such stressful conditions is mainly centered in the activation of the sympathetic system and the hypothalamic- hypophysis- adrenal axis through catecholamine and glucocorticoid production [36]. Shearing usually results in an enhancement of energy exchange between the animal and its surroundings, and this may affect the productivity and welfare of the sheep [3].

Domestic animals react to stress by alerting their behavioral and physiological responses, which result from their individual emotional reactivity [21]. The physiological response to stress includes activation of the central nervous system and the endocrine and immune systems, and it can affect the animal's production performance. In sheep, different studies have demonstrated the worsening of production performance in response to stressful management procedures [16, 45].

Wool shearing is one of the management practices that can influence the success of sheep growing. Wool shearing is usually applied by farmers to minimize external parasites that could cause health problems. In addition, farmers believe that shearing sheep would improve growth performance and could make them more adaptable to the environment [40].

Shearing is considered to be stressful to sheep, capable of causing some behavioral changes, including comfort behaviors that change immediately after shearing [4,9] and results in thermal stress [17]. Stressful conditions lead to excessive production of free radicals, which results in oxidative stress. This is commonly defined as an imbalance between oxidants and antioxidants in favor of oxidants at the cellular level [39]. Oxidative stress causes cellular injuries in cells and tissues in the form of lipid peroxidation which includes malondialdehyde (MDA) [42] and cytokines [19]. Determination of MDA [20], catalase and glutathione reductase [18] allows the detection of the degree of oxidative stress in ruminants [1].

The aim of this work was to investigate the effect of shearing on some welfare parameters, antioxidants, and inflammatory and stress biomarkers in Ossimi sheep. 
Table 1. Behavioral ethogram of sheep

\begin{tabular}{ll}
\hline \multicolumn{1}{c}{ Behavior } & \multicolumn{1}{c}{ Description } \\
\hline Grooming & Sheep scratch the accessible parts of the body with their teeth or claws \\
Rumination & Regurgitation of food from the rumen; re-chewing and re-swallowing it \\
Grazing & Sheep collect vegetation from the ground \\
Walking & Move from one point to another \\
Standing idle & Pointless positioning of all four feet \\
\hline
\end{tabular}

\section{MATERIALS AND METHODS}

The current study procedures were carried out according to the guidelines of the faculty of veterinary medicine Benha University for the use of animals under ethics approval no (fvtm.bu/01).

This study was carried out in September 2017 with a flock of 60 clinically healthy Ossimi rams (average body weight 30 $\pm 2.3 \mathrm{~kg}$, aged between 1-2 years). Sheep health status was evaluated daily, based on behavior, rectal temperature, heart rate, respiration, cough, nasal and eye discharges, appetite, ruminal movements, and the physical characteristics of the fecal matter.

The environmental temperature and humidity levels were recorded during the experimental period. The average environmental temperature was $31^{\circ} \mathrm{C}$, and the average relative humidity was $75 \%$. During the day, the animals grazed on natural pasture, and they were penned at night, where they received a concentrate ration of $250 \mathrm{~g}$ per head (crude protein $18 \%$ ), with free access to hay and water ad libitum.

\section{Experimental procedures}

Blood sampling. Blood samples were collected from the animals just before shearing, and then at 1, 5, 10 and 15 days after shearing. Serum was used to measure Catalase (CAT), Glutathione reductase (GSH-R), Malondaldyhde (MDA), Interleukin 6 (IL6), Interleukin 2 (IL2), Tumor necrosis factor alpha (TNF- $\alpha$ ) and cortisol.

Behavioral observation. Behavioral patterns were recorded by means of live observations. Each animal was observed for 10 min once per week through continuous focal sampling [5]. The behavioral patterns of each animal were recorded pre-shearing, and on the 1st, 5th, 10th, and 15th day post-shearing. The behaviors recorded during the study are presented in Table 1.

Biochemical analysis. Serum cortisol concentrations were determined using an ELISA kit (Eucardio Laboratory, Inc., Encinitas, CA., U.S.A.). CAT levels were determined using the methods described by Goth [27]. TNF- $\alpha$, IL-6 and IL-2 levels were determined with ELISA according to the methods described by Fan et al. [24]. MDA levels were determined using the methods described by Draper and Hardley [22]. GSH-R levels were determined according to Bulfield and Moore [11].

Statistical analysis. The obtained results from the experiments were expressed as means \pm SEM and were analyzed by analysis of variance (ANOVA) for repeated measures using SPSS Statistics for Windows, version 23.0 (IBM Corp: Armonk, NY, U.S.A.). Differences were declared significant when $(P<0.05)$.

\section{RESULTS}

\section{Clinical and behavioral observations}

Rectal temperature, pulse, and respiratory rates increased until the 5th day post-shearing. Rumination, grazing, and walking were not significantly affected by shearing, while there was a significant $(P<0.01)$ increase in frequency of grooming post-shearing, especially on the 10th and 15th day. Shearing also significantly increased the frequency of standing $(P<0.05)$, (Table 2, Fig. 1).

\section{Biochemical analysis}

There were significant $(P<0.01)$ increases in IL-6, cortisol, and MDA from the 1st to the 10th day post-shearing compared to pre-shearing values, while at the 15 th day there were no significant differences from pre-shearing values. IL- 2 and TNF- $\alpha$ significantly $(P<0.01)$ increased from the 1 st to the 5 th day post-shearing compared to pre-shearing values, while there were no significant differences from the 10th day. Significant $(P<0.01)$ decreases in the values of CAT from the 1st to the 5th day postshearing compared to pre-shearing values were recorded. Regarding to GSH-R, there was a significant $(P<0.01)$ decrease from the 1 st until the 10th days post-shearing compared to pre-shearing values, while there was no significant difference at the 15 th day from the pre-shearing values (Table 3, Fig. 2).

\section{DISCUSSION}

Evaluation of the effect of shearing on some welfare parameters, antioxidants, and inflammatory and stress biomarkers in Ossimi sheep revealed significant alterations in some clinical, behavioral and biochemical parameters regarding to oxidative stress.

\section{Clinical and behavioral observations}

The physical stress of shearing produced a transient increase in rectal temperature in terms of stress-induced hyperthermia 
Table 2. Frequency of sheep behavioral patterns pre and post-shearing

\begin{tabular}{lccccc}
\hline \multirow{2}{*}{ Behavior } & \multirow{2}{*}{ Pre-shearing } & \multicolumn{4}{c}{ Post -shearing } \\
\cline { 3 - 6 } & & 1st day & 5th day & 10th day & 15th day \\
\hline Grooming & $7.5 \pm 0.68^{\mathrm{b})}$ & $8 \pm 0.68^{\mathrm{b})}$ & $9.66 \pm 0.68^{\mathrm{b})}$ & $14 \pm 0.68^{\mathrm{a})}$ & $15 \pm 0.83^{\mathrm{a})}$ \\
Rumination & $8 \pm 0.67$ & $8.16 \pm 0.67$ & $8.33 \pm 0.67$ & $7 \pm 0.67$ & $5 \pm 0.82$ \\
Grazing & $9 \pm 0.62$ & $10.66 \pm 0.62$ & $10 \pm 0.62$ & $9.83 \pm 0.62$ & $9.86 \pm 0.76$ \\
Walking & $6.73 \pm 0.86$ & $7.33 \pm 0.86$ & $8.33 \pm 0.86$ & $9.66 \pm 0.86$ & $6.50 \pm 1.06$ \\
Standing idle & $1.30 \pm 0.68^{\mathrm{b})}$ & $6 \pm 0.68^{\mathrm{a})}$ & $4 \pm 0.68^{\mathrm{a})}$ & $3.66 \pm 0.68^{\mathrm{a})}$ & $3 \pm 0.83^{\mathrm{a})}$ \\
\hline
\end{tabular}

Means $( \pm \mathrm{SE})$ in the same row with different superscript letters are significantly different when $(P<0.05)$.

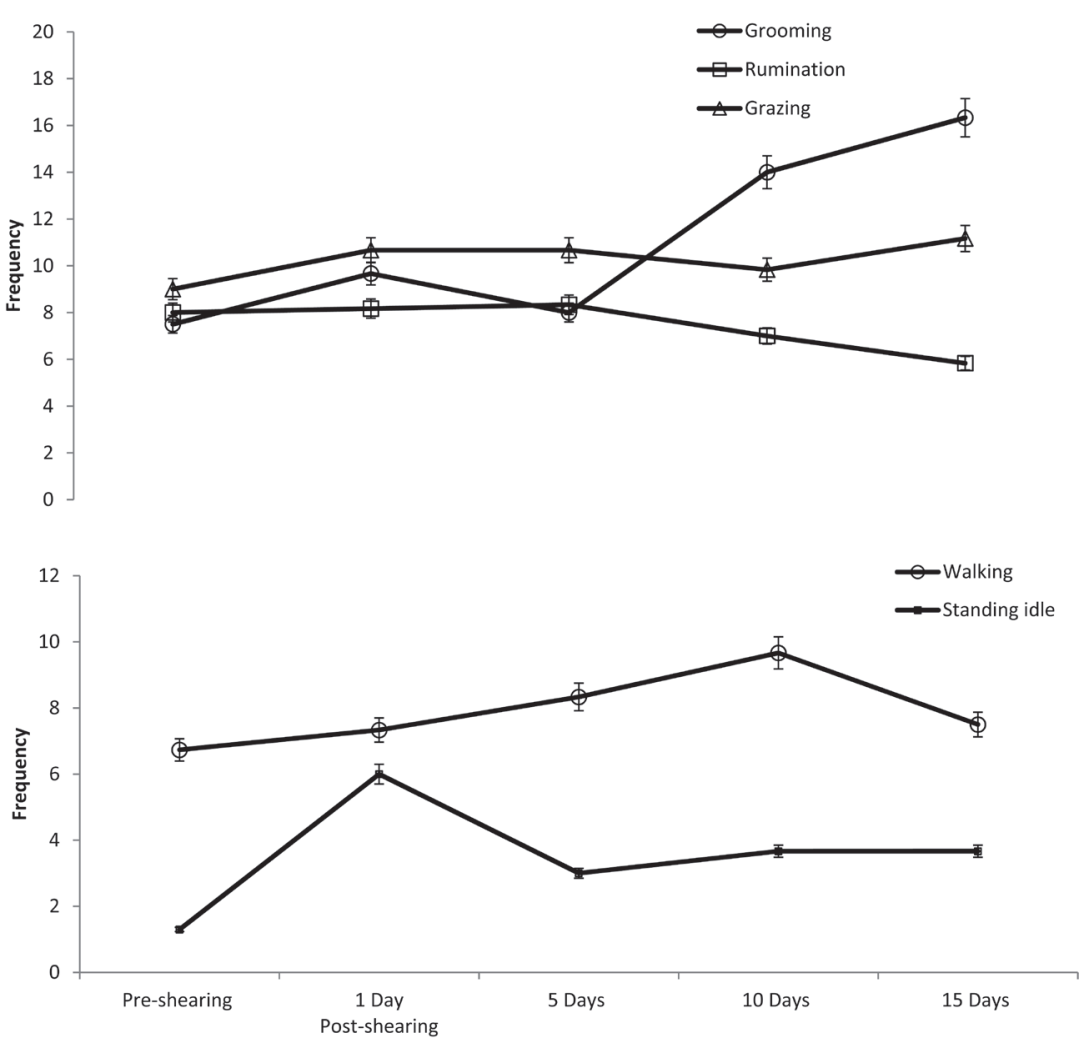

Fig. 1. Frequency of sheep behavioral patterns pre-shearing and at $1,5,10$, and 15 days post-shearing.

$[17,48]$, which coincided with the current study. The increased respiratory rate probably occurred because it tends to closely follow heat loss by evaporation [38]. Heart rate showed a similar trend in respect to respiratory rate due to the direct effect of heat stress inducing hemodynamic adaptations, because the animals produced high quantities of heat dispersed by an enlarged peripheral vascular system [40].

The shearing process significantly affects grooming behaviors, as the frequency of grooming among shorn sheep was higher compared to that of unshorn sheep. The current result agrees with Naglaa et al. [37] who found that there were no significant differences in the behaviors of shorn and unshorn ewes, except in grooming behaviors which were significantly greater among the shorn ewes. The increase in grooming behaviors post-shearing may be attributed to the stimulus effect of shearing in the skin of sheep, which initiates grooming. The current results also agree with Benjamin and Patricia [9] and Hart and Pryor [30], who studied the effect of the shearing process on grooming and reported that immediately after shearing the skin shows different bouts of cutaneous stimuli leading to an increase in grooming behaviors.

Although frequency of rumination decreased at the 10th and 15th day post-shearing, the effect of shearing was not significant. Additionally, the results showed that shearing had no significant effect on grazing. This may be attributable to the fact that the sheep received the same type and amount of food, and they grazed at the same pasture both before and after shearing. Previous studies $[8,37]$ reported no change in food intake and feeding behaviors in shorn and fleeced sheep. Badawy et al. [6] stated that shorn sheep showed a decline in rumination frequency compared with unshorn sheep.

The current results showed variations in walking frequencies of sheep. Higher levels of walking were recorded at the 1st, 5th, and 10th day post-shearing. This increase in walking activities may be attributable to the painful effect or fear reaction resulting 
Table 3. Biochemical parameters of sheep pre and post-shearing

\begin{tabular}{|c|c|c|c|c|c|}
\hline \multirow{2}{*}{ Parameters } & \multirow{2}{*}{ Pre-shearing } & \multicolumn{4}{|c|}{ Post-shearing } \\
\hline & & 1st day & 5th day & 10th day & 15 th day \\
\hline IL6 $(\mu \mathrm{g} / \mathrm{m} l)$ & $6.54 \pm 0.65^{\mathrm{b})}$ & $13.94 \pm 1.3^{\text {a) }}$ & $15.53 \pm 2.1^{\text {a) }}$ & $12.42 \pm 0.90^{\mathrm{a})}$ & $7.46 \pm 0.47^{b)}$ \\
\hline $\operatorname{IL} 2(\mu \mathrm{g} / \mathrm{m} l)$ & $0.37 \pm 0.07^{b)}$ & $\left.0.85 \pm 0.08^{a}\right)$ & $1.15 \pm 0.56^{\mathrm{a})}$ & $0.55 \pm 0.02^{b)}$ & $0.48 \pm 0.05^{b)}$ \\
\hline Cortisol $(\mu \mathrm{g} / \mathrm{d} l)$ & $6.96 \pm 0.82^{\mathrm{b})}$ & $20.64 \pm 2.5^{\mathrm{a})}$ & $23.79 \pm 1.9^{\mathrm{a})}$ & $\left.11.58 \pm 0.84^{a}\right)$ & $9.55 \pm 0.49^{b)}$ \\
\hline $\mathrm{TNF}-\alpha(\mathrm{U} / \mathrm{m} l)$ & $30.25 \pm 1.9^{b)}$ & $63.73 \pm 6.2^{\mathrm{a})}$ & $52.88 \pm 2.3^{\text {a) }}$ & $39.72 \pm 1.6^{\mathrm{b})}$ & $30.95 \pm 1.4^{b)}$ \\
\hline CAT $(\mathrm{kU} / l)$ & $43.65 \pm 3.9^{\mathrm{a})}$ & $19.46 \pm 2.03^{b)}$ & $18.68 \pm 2.4^{\mathrm{b})}$ & $35.39 \pm 3.02^{\mathrm{a})}$ & $41.72 \pm 3.3^{\mathrm{a})}$ \\
\hline GSH-R $(\mathrm{kU} / l)$ & $7.7 \pm 0.5^{\mathrm{a})}$ & $3.6 \pm 0.2^{\mathrm{b})}$ & $3.3 \pm 0.7^{\mathrm{b})}$ & $6.1 \pm 0.4^{\mathrm{b})}$ & $7.8 \pm 0.3^{\mathrm{a})}$ \\
\hline $\mathrm{MDA}(\mathrm{mmol} / l)$ & $0.66 \pm 0.6^{b)}$ & $1.2 \pm 0.5^{\mathrm{a})}$ & $1.3 \pm 0.7^{\mathrm{a})}$ & $0.97 \pm 0.4^{\mathrm{a})}$ & $0.67 \pm 0.5^{b)}$ \\
\hline
\end{tabular}

Means ( \pm SE) in the same row with different superscript letters are significantly different when $(P<0.05)$.
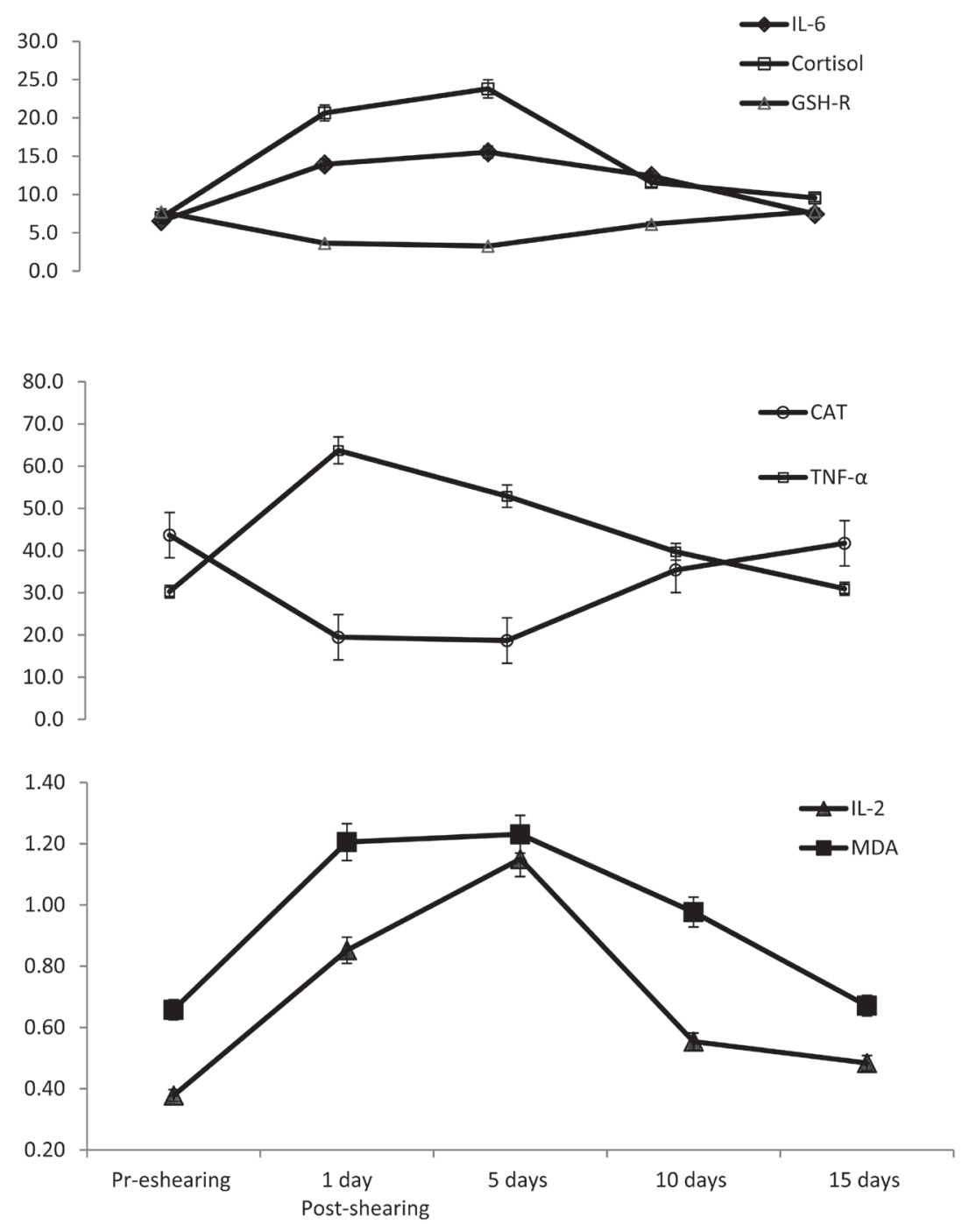

Fig. 2. Biochemical parameters of sheep pre-shearing and at 1,5,10, and 15 days post-shearing.

from the shearing process, as reported by Badawy et al. [6]. On the 15th day after shearing, walking frequency decreased, which may be attributable to the sheep's adaptation to post-shearing conditions.

The current results revealed higher frequencies of standing post-shearing compared to pre-shearing as a sign of stress resulting from shearing [44]. Teresa et al. [47] reported that unshorn sheep stood less than the shorn sheep $(P<0.05)$. This was dissimilar to the results of Naglaa et al. [37] who found no effect of shearing on standing idle among shorn and unshorn sheep. 


\section{Biochemical analysis}

Stress has been defined as the cumulative response of an animal resulting from interactions with its environment via receptors [26]. Blood cortisol levels were higher post-shearing than in pre-shearing; the high levels were maintained at the same rate between the 1st and 10th day post-shearing. The rise in blood cortisol levels that was observed post-shearing coincided with previous reports $[13,28]$. Several studies have demonstrated that plasma cortisol concentrations increase in sheep in response to stressors, like the shearing process $[25,28,34,41]$. In agreement with this finding, the present study recorded, marked elevations in plasma cortisol concentrations post-shearing, suggesting that shearing by itself would be a stressful event.

In the present study, the shearing procedure induced a significant increase in blood MDA concentrations, indicating the occurrence of oxidative stress. Increase in MDA was interpreted as a marker of excess free radical production [1] in sheep postshearing. Lipids are the most susceptible substrates to free radical damage. MDA is the last product of lipid peroxidation, and is a key marker of oxidative stress [18]. Various studies have reported that lipid peroxidation products, such as MDA, increase in diseased and some managemental conditions as transportation [2]. On the other hand, the antioxidant defense systems include small molecular antioxidants and antioxidant enzymes like CAT and GSH-R [25].

Increased production of free radicals as hydrogen peroxide under stressful conditions leads to augmented oxidative stress, resulting in enhanced lipid peroxidation and MDA production [43] as well as reduction in CAT [32, 35] and GSH-R [23]. This agrees with the results of the current study, which can be induced under some conditions by exposure to oxidative stress during some management procedures as is the case with sheep during shearing. Therefore, GSH-R can be considered a special system of antioxidant enzymes controls the concentrations and fluxes of superoxide radicals, hydrogen peroxide, and the reactive products $[12,33]$. A stressful condition leads to the excessive production of free radicals, which results in the oxidative stress associated with an imbalance between oxidants and antioxidants in favor of oxidants at the cellular level [31, 39, 46]. This result could be explained by the occurrence of free radicals due to the stress factors present during the shearing process. Stressors can determine the secretion of pro-inflammatory cytokines IL-2, IL- 6 , and TNF- $\alpha$. In turn, cytokine production and actions are controlled by cortisol $[10,14]$. The direct relationship found between the plasma cortisol and cytokine concentration [15, 19] results from this study demonstrated that, significant increases in cortisol, IL-2, IL-6, and TNF- $\alpha$ levels post-shearing were considered to be stressors.

In conclusion, the shearing procedure may be considered a stressful condition, as evidenced by the significant increase in cortisol, MDA, IL-6, IL-2, and TNF- $\alpha$ concentrations associated with decreased GSH-R and CAT concentrations, as well as clinical and behavioral changes. The increases in plasma cortisol and MDA concentrations in response to shearing could be additional factors responsible for oxidative stress. The determination of oxidative stress parameters could be a new approach for evaluating stress in sheep, and antioxidant treatment is recommended for decreasing stressful condition that resulted from shearing.

CONFLICT OF INTEREST. The authors declare no conflict of interest.

\section{REFERENCES}

1. Aktas, M. S., Kandemir, F. M., Kirbas, A., Hanedan, B. and Aydin, M. A. 2017. Evaluation of oxidative stress in sheep infected with Psoroptes ovis using total antioxidant capacity, total oxidant status, and malondialdehyde level. J. Vet. Res. (Pulawy) 61: 197-201.

2. Aktas, M. S., Ozkanlar, S., Karakoc, A., Akcay, F. and Ozkanlar, Y. 2011. Efficacy of vitamin E+selenium and vitamin A+D+E combinations on oxidative stress induced by long-term transportation in holstein dairy cows. Livest. Sci. 141: 76-79. [CrossRef]

3. Aleksiev, Y. 2008. Effect of shearing on some physiological respponses in lactating ewes kept indoor. Bulg. J. Agric. Sci. 14: 417-423.

4. Aleksiev, Y. 2009. The effect of shearing on the behaviour of some physiological responses in lactating pleven blackhead ewes. Bulg. J. Agric. Sci. 15: 446-452.

5. Averós, X., Loreaa, A., de Herediaa, I. B., Ruiz, R., Marchewkaa, J., Arranz, J. and Estevez, I. 2014. The behaviour of gestating dairy ewes under different space allowances. Appl. Anim. Behav. Sci. 150: 17-26. [CrossRef]

6. Badawy, M. T. A., Gawish, H. A., Abdel-Fattah, M. S. and Azamel, A. A. 2008. Behaviour and physiological responses of aboudelik sheep to shearing stress in halaibshalateen-abouramad triangle. Egyptian J. Anim. Prod. 45: 119-129.

7. Baldock, N. M. and Sibly, R. M. 1990. Effect of handling and transportation on the heart rate and behaviour of sheep. Appl. Anim. Behav. Sci. 28: 15-39. [CrossRef]

8. Beatty, D. T., Barnes, A., Fleming, P. A., Taylor, E. and Maloney, S. K. 2008. The effect on core and rumen temperature in sheep. J. Therm. Biol. 33: 437-443. [CrossRef]

9. Benjamin, L. H. and Patricia, P. A. 2004. Developmental and hair-coat determinants of grooming behavior in goats and sheep. Anim. Behav. 67: 11-19. [CrossRef]

10. Black, P. H. 2002. Stress and the inflammatory response: a review of neurogenic inflammation. Brain Behav. Immun. 16: 622-653. [Medline] [CrossRef]

11. Bulfield, G. and Moore, E. A. 1974. Semi-automated assays for enzymopathies of carbohydrate metabolism in liver and erythrocytes, using a reaction rate analyser. Clin. Chim. Acta 53: 265-271. [Medline] [CrossRef]

12. Cadenas, E. and Davies, K. J. 2000. Mitochondrial free radical generation, oxidative stress, and aging. Free Radic. Biol. Med. 29: $222-230$. [Medline] [CrossRef]

13. Carcangiu, V., Vacca, G. M., Parmeggiani, A., Mura, M. C., Pazzola, M., Dettori, M. L. and Bini, P. P. 2008. The effect of shearing procedures on blood levels of growth hormone, cortisol and other stress haematochemical parameters in Sarda sheep. Animal 2: 606-612. [Medline] [CrossRef]

14. Caroprese, M., Albenzio, M., Annicchiarico, G. and Sevi, A. 2006. Changes occurring in immune responsiveness of single- and twin-bearing Comisana ewes during the transition period. J. Dairy Sci. 89: 562-568. [Medline] [CrossRef]

15. Caroprese, M., Albenzio, M., Marzano, A., Schena, L., Annicchiarico, G. and Sevi, A. 2010. Relationship between cortisol response to stress and 
behavior, immune profile, and production performance of dairy ewes. J. Dairy Sci. 93: 2395-2403. [Medline] [CrossRef]

16. Caroprese, M., Annicchiarico, G., Schena, L., Muscio, A., Migliore, R. and Sevi, A. 2009. Influence of space allowance and housing conditions on the welfare, immune response and production performance of dairy ewes. J. Dairy Res. 76: 66-73. [Medline] [CrossRef]

17. Casella, S., Giudice, E., Passantino, A., Zumbo, A., Dipietri, S. and Piccione, G. 2016. Shearing induces secondary biomarkers responses of thermal stress in sheep. Anim. Sci. Pap. Rep. 34: 73-80.

18. Celi, P. 2010. The role of oxidative stress in small ruminants' health and production. Rev. Bras. Zootec. 39: 348-363. [CrossRef]

19. Ciliberti, M. G., Albenzio, M., Inghese, C., Santillo, A., Marino, R., Sevi, A. and Caroprese, M. 2017. Peripheral blood mononuclear cell proliferation and cytokine production in sheep as affected by cortisol level and duration of stress. J. Dairy Sci. 100: 750-756. [Medline] [CrossRef]

20. Deger, S., Deger, Y., Bicek, K., Ozdal, N. and Gul, A. 2009. Status of lipid peroxidation, antioxidants, and oxidation products of nitric oxide in equine babesiosis: status of antioxidant and oxidant in equine babesiosis. J. Equine Vet. Sci. 29: 743-747. [CrossRef]

21. Deiss, V., Temple, D., Ligout, S., Racine, C., Bouix, J., Terlouw, C. and Boissy, A. 2009. Can emotional reactivity predict stress responses at slaughter in sheep? Appl. Anim. Behav. Sci. 119: 193-202. [CrossRef]

22. Draper, H. H. and Hadley, M. 1990. Malondialdehyde determination as index of lipid peroxidation. Methods Enzymol. 186: 421-431. [Medline] [CrossRef]

23. Esmaeilnejad, B., Tavassoli, M., Asri-Rezaei, S. and Dalir-Naghadeh, B. 2012. Evaluation of antioxidant status and oxidative stress in sheep naturally infected with Babesia ovis. Vet. Parasitol. 185: 124-130. [Medline] [CrossRef]

24. Fan, W., Liu, X. and Yue, J. 2012. Determination of urine tumor necrosis factor, IL-6, IL-8, and serum IL-6 in patients with hemorrhagic fever with renal syndrome. Braz. J. Infect. Dis. 16: 527-530. [Medline] [CrossRef]

25. Fidan, A. F., Kucukkurt, I., Eryavuz, A., Cigerci, I. H., Yardimci, M. and Ozdemir, A. 2009. Effects of shearing procedures on oxidantantioxidant status in Chios sheep. Effects of shearing procedures on oxidantantioxidant status in Chios sheep. Rev. Med. Vet. (Toulouse) 160: $349-355$.

26. Fowler, M. E. 1995. Restraint and Handling of Wild and Domestic Animals. 2nd ed., (Murray, E. F. ed.), Iowa State University Press, Ames.

27. Góth, L. 1991. A simple method for determination of serum catalase activity and revision of reference range. Clin. Chim. Acta 196: 143-151. [Medline] [CrossRef]

28. Hargreaves, A. L. and Huston, G. D. 1990. The stress response in sheep during routine handling procedures. Appl. Anim. Behav. Sci. 26: 83-90. [CrossRef]

29. Hargreaves, A. L. and Hutson, G. D. 1990. Changes in heart rate, plasma cortisol and haematocrit of sheep during a shearing procedure. Appl. Anim. Behav. Sci. 26: 91-101. [CrossRef]

30. Hart, B. L. and Pryor, P. A. 2004. Development and hair-coat determents of grooming behaviour in goats and sheep. Anim. Behav. 67: 11-19. [CrossRef]

31. Kirschvink, N., de Moffarts, B. and Lekeux, P. 2008. The oxidant/antioxidant equilibrium in horses. Vet. J. 177: 178-191. [Medline] [CrossRef]

32. Masters, C., Pegg, M. and Crane, D. 1986. On the multiplicity of the enzyme catalase in mammalian liver. Mol. Cell. Biochem. 70: 113-120. [Medline] [CrossRef]

33. McCord, J. M. and Edeas, M. A. 2005. SOD, oxidative stress and human pathologies: a brief history and a future vision. Biomed. Pharmacother. 59: 139-142. [Medline] [CrossRef]

34. Mears, G. J., Brown, F. A., Redmond, L. R. and 38. 1999. Effects of handling, shearing and previous exposure to shearing on cortisol and betaendorphin responses in ewes. Can. J. Anim. Sci. 79: 35-38. [CrossRef]

35. Michiels, C., Raes, M., Toussaint, O. and Remacle, J. 1994. Importance of Se-glutathione peroxidase, catalase, and Cu/Zn-SOD for cell survival against oxidative stress. Free Radic. Biol. Med. 17: 235-248. [Medline] [CrossRef]

36. Miller, D. B. and O'Callaghan, J. P. 2002. Neuroendocrine aspects of the response to stress. Metabolism 51 Suppl 1: 5-10. [Medline] [CrossRef]

37. Naglaa, M. M., Emeash, H. H., El-Bably, M. A. and Safa Nadi, A. 2012. Stress resulting of management practices on sheep herds. Egypt J.sheep\&goat. Sci. 7: 1-10.

38. Pennisi, P., Costa, A., Biondi, L., Avondo, M. and Piccione, G. 2001. Influence of the fleece on the thermal homeostasis and body condition in Comisana ewe lambs. Anim. Res. 53: 13-19. [CrossRef]

39. Piccione, G., Fazio, F., Casella, S., Pennisi, P. and Caola, G. 2011. Influence of shearing on oxidative stress and some physiological parameters in ewes. Anim. Sci. J. 82: 481-485. [Medline] [CrossRef]

40. Piccione, G., Lutri, L., Casella, S., Ferrantelli, V. and Pennisi, P. 2008. Effect of shearing and environmental conditions on physiological mechanisms in ewes. J. Environ. Biol. 29: 877-880. [Medline]

41. Pierzchala, K., Bobek, S., Niezgoda, J. and Ewy, Z. 1983. The effect of shearing on the concentration of cortisol and thyroid hormones in the blood plasma of sheep. Zentralbl. Veterinarmed. A 30: 749-759. [Medline] [CrossRef]

42. Romero, F. J., Bosch-Morell, F., Romero, M. J., Jareño, E. J., Romero, B., Marín, N. and Romá, J. 1998. Lipid peroxidation products and antioxidants in human disease. Environ. Health Perspect. 106 Suppl 5: 1229-1234. [Medline] [CrossRef]

43. Saleh, M. A. 2009. Erythrocytic oxidative damage in crossbred cattle naturally infected with Babesia bigemina. Res. Vet. Sci. 86: 43-48. [Medline] [CrossRef]

44. Serdal, D., Abdulkadir, O. and Hakan, U. 2011. The effect of shearing in a hot environment on some welfare indicators in Awassi lambs. Trop. Anim. Health Prod. 43: 1327-1335. [Medline] [CrossRef]

45. Sevi, A., Annicchiarico, G., Albenzio, M., Taibi, L., Muscio, A. and Dell'Aquila, S. 2001. Effects of solar radiation and feeding time on behavior, immune response and production of lactating ewes under high ambient temperature. J. Dairy Sci. 84: 629-640. [Medline] [CrossRef]

46. Sies, H. 1991. Oxidative stress: from basic research to clinical application. Am. J. Med. 91 3C: 31S-38S. [Medline] [CrossRef]

47. Teresa, C., Sarah, W., Barnes, A., Miller, D. and Trish, F. 2016. The effect of shearing on sheep feeding and behavior. Proceedings of AVA Annual Conference, Adelaide.

48. Waltz, X., Baillot, M., Connes, P., Bocage, B. and Renaudeau, D. 2014. Effects of hydration level and heat stress on thermoregulatory responses, hematological and blood rheological properties in growing pigs. PLoS One 9: e102537. [Medline] [CrossRef] 